\author{
Amin Salih Mohammed ${ }^{1,2}$, Saravana Balaji B. ${ }^{1}$, Saleem Basha M. S. ${ }^{3}$ \\ ${ }^{1}$ Lebanese French University, Erbil, Kurdistan Region, Iraq \\ ${ }^{2}$ Salahaddin University, Erbil, Kurdistan Region, Iraq \\ ${ }^{3}$ Mazoon College, Muscat, Oman
}

\title{
FUZZY APPLIED ENERGY AWARE CLUSTERING BASED ROUTING FOR IOT NETWORKS
}

\begin{abstract}
The Internet of Things (IoT) depends on interconnection of clever and addressable gadgets, permitting their self-sufficiency and proactive conduct with Internet availability. Information dispersal in IoT normally relies upon the application and requires setting mindful steering conventions that must incorporate auto-setup highlights (which adjust the conduct of the system at runtime, in light of setting data). This paper proposes a methodology for IoT course determination utilizing fuzzy rationale so as to accomplish the necessities of explicit applications. For this situation, fuzzy rationale is utilized to decipher in math terms the uncertain data communicated by a lot of phonetic guidelines. The criteria of vitality status, QoS effect and hub area are taken as the fundamental factors that can impact the choice of group heads while every measure contains some sub-criteria. For routing, FEACR - Fuzzy applied energy aware clustering based routing for IoT Networks is utilized to upgrade the information conveyance dependability. The bunch based directing is a proficient way to diminish the vitality utilization. From the tests led in this examination work utilizing the proposed model, it is demonstrated that the proposed directing calculation gave better system execution as far as the measurements to be specific defer time, packet conveyance proportion, and system lifetime.
\end{abstract}

Keyw ords : Internet of Things; Routing; Fuzzy Clustering; Sensors.

\section{Introduction}

Wireless sensor network is a blend of remote systems which is consolidated in an extended mix of disseminated self-sufficient gadget. The exceptional self-governing gadget utilizing the sensor to redress the physical and natural conditions. Web of Things (IoT) is an ongoing and developing examination territory of social, specialized and financial importance [1]. It empowers the machine to machine correspondence over the web, without human association [2-4]. The basic structure of Internet of Things (IoT) is given in Fig. 1.

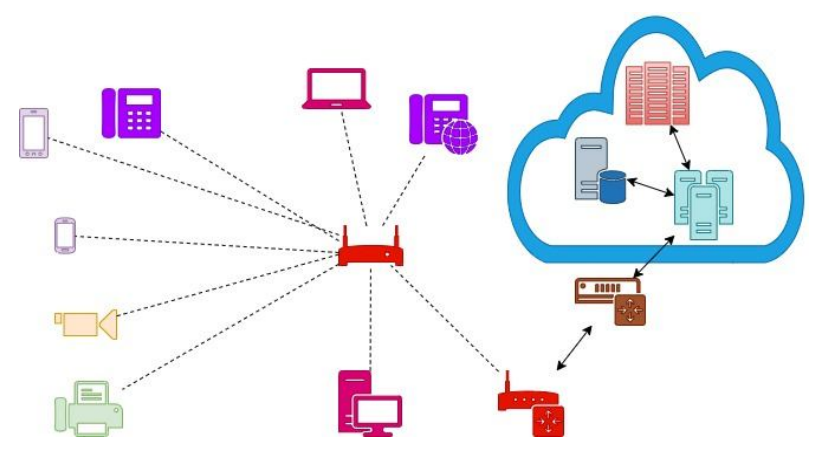

Fig. 1. IoT Structure

These days, the individuals are utilizing IoT application, for example, brilliant home, keen city, social insurance, wearable, savvy framework, associated vehicle, shrewd retail, keen store network and keen cultivating [3]. Among the most encouraging advancements for the IoT worldview, RFID and Wireless Sensor Networks (WSNs) are the most wellknown and fitting $[5,6]$. WSNs have restrictions on the distinguishing proof of an individual or article in certain kinds of utilizations. Notwithstanding, not at all like WSNs, RFID frameworks can't detect information from the spot in which they are utilized, for example, stickiness, temperature and weight that are given by sensors. This means IoT, by methods for the coordination between the RFID and WSN advancements, boosts the advantages, subsequently opening up new viewpoints for applications that think about setting data, for example, temperature checking in remote zones and air nature of a particular city or locale, vehicle control streams, among others. Accordingly, the things outfitted with sensors in IoT organize have constrained registering, memory, handset module and power capacities, along these lines, convey in a shortextend separation [7]. In IoT, the vitality imperative is an urgent issue, as things are generally worked on constrained battery control. LLN is a system, which made out of asset compelled gadgets interconnected by the remote connections [8]. Directing assumes a crucial job for vitality protection in Low power and lossy systems (LLN). In LLN, the directing convention has the requirements like low information handling limit, constrained memory and vitality. In addition, LLN steering configuration need to self-compose the system hubs; by recuperating itself without manual contribution [9]. The acknowledgment of vitality productive directing to accomplish a savvy correspondence in IoT is the examination target of this paper. Numerous vitality productive plans for different systems, for example, remote sensor systems (WSN) [10-12] and specially appointed systems [13-15] have been generally proposed in the ongoing past to drag out system lifetime by diminishing the vitality utilization of sensor hubs. Be that as it may, the conventional vitality proficient steering measurements characterized for WSN and specially appointed systems are not suitable in IoT because of its dynamic system topology, inhumane packet misfortune, information rates, connect limit, interface quality, channel decent variety, impedance, and different other directing necessities [1].Clustering and multi-jump directing is the normal way to deal with improve vitality productivity of the system. Rather than 
giving every hub access the system forward its very own data to the base station legitimately, they are assembled into various bunches. In view of certain criteria, a bunch head $(\mathrm{CH})$ hub is chosen in each group. The $\mathrm{CH}$ hub will assemble data from other bunch part hubs and afterward forward the prepared data to base station by means of different bounces utilizing other $\mathrm{CH}$ hubs. The advantage of such plan is twofold. To begin with, the $\mathrm{CH}$ hub can pack the information gathered from group part hubs to decrease undesirable excess. Second, the vitality proficiency is extraordinarily improved by giving most hubs access the system transmit to a close by $\mathrm{CH}$ hub, and constraining the various jump correspondence to $\mathrm{CH}$ hubs as it were. The paper is sorted out as pursues: Section 2 depicts the related work. Segment 3 depicts the Proposed Routing convention plan. Section 4 speaks to the exhibition assessment. At last, we finish up and examine the future work in segment 5 .

\section{Related Work}

In [16] creators have displayed a Survivable Path Routing in WSN for IoT applications. This paper presents a clog and impedance mindful vitality productive directing framework for WSN explicitly, Survivable Path Routing. This convention work in the frameworks with high traffic considering the way that various sources try to send their packets to an objective meanwhile, which is a customary circumstance in IoT applications for remote restorative administrations watching. For picking the following bounce hub, the calculation uses a rule which is a segment of three factors: sign to obstruction and clamor proportion of the connection, the survivability factors the way from the following jump hub to the goal, and the blockage level at the following jump hub. Entertainment results suggest that the presented convention works better concerning the framework throughput, start to finish delay, packet conveyance proportion and the rest of the vitality level of the hubs. In [16], the creators proposed a calculation that controls the likelihood of sending RREQ packets as per the lingering vitality of the hub. A vitality proficient directing convention dependent on AODV convention by considering the transmission control and remaining vitality limit of the portable hubs is proposed in [17]. Also, the likelihood based improved telecom calculation [18] lessens the RREQ messages by utilizing a telecom likelihood together with the thought of the leftover vitality of hubs. In [19], the creators utilized fuzzy standards for choosing reasonable bunch takes and for take away the steering procedure through the group heads. Such models gave improvement in execution upto a specific degree. Nonetheless, the precision is to be upgraded further for settling on progressively exact choices. The fuzzy guidelines can be extended by thinking about extra number of traits. Thusly in [20], the creators built up a fuzzy based directing model by considering the factors to be specific separation and vitality. Be that as it may, the vitality effectiveness issue couldn't be tackled completely because of the idea of the sensor hubs. Thus, it is important to consider a superior learning system that can be incorporated with fuzzy rationale in-order to deal with the vulnerability issue and to perform powerful expectation. Mhemedet. al. [121] proposed another methodology on group arrangement. In their work, fuzzy rationale was utilized to shape the groups in arrange dependent on three parameters to be specific vitality, separation of hubs from bunch head and the separation of the sink hub. They have demonstrated the upgrade in the system life length of WSN. In [22], creators proposed fuzzy rationale approach for inconsistent bunching. The creators utilized $\mathrm{CH}$ degree and the separation to the sink for the decision of $\mathrm{CH}$. Taheri et al. [23] proposed another and vitality mindful steering convention which is additionally a circulated and dynamic grouping based convention that utilizations three stages in particular probabilistic $\mathrm{CH}$ political race process, use of fuzzy rationale for basic leadership and the arrangement of on request bunching. Their model spotlights on all rounds and thus it performs grouping persistently like the LEACH convention. The HEED calculation which was proposed by Younis and Fahmy [24] is a vitality productive group based steering calculation that chooses the bunch heads haphazardly by utilizing the likelihood esteems so as to perform bunch based directing viably. In any case, HEED changes the $\mathrm{CHs}$ all the more consistently over the sensor arrange in numerous cycles among littler group ranges. In addition, every hub in HEED calculation can turn into a $\mathrm{CH}$ through pivot approach utilizing its own likelihood esteems when the calculation is hearing no bunch headannouncement from the neighbor hubs. The primary favorable position of HEED is that the $\mathrm{CHs}$ are chosen dependent on the revolution strategy. Also, the choice procedure has been improved by applying rules all the more adequately. In any case, the vast majority of the above talked about calculations took a shot at $\mathrm{CH}$ determination utilizing fuzzy rationale and just a couple dealt with group development. Moreover, the current works concentrated on basic leadership utilizing fuzzy rationale and considered directing without profound learning of the system [22] and [24].Authors in [27] propose a new protocol called neuro-fuzzy based cluster formation protocol (FBCFP), which performs learning of the network by considering four important components namely current energy level of the $\mathrm{CH}$, distance of the $\mathrm{CH}$ from the sink node, change in area between the nodes present in the cluster and the $\mathrm{CH}$ due to mobility and the degree of the $\mathrm{CH}$. For this purpose, the network is trained with convolutional neural network with fuzzy rules for weight adjustment. Authors in [26] introduced adaptive fuzzy rule based energy efficient clustering and immuneinspired routing (FEEC-IIR) protocol for WSN assisted IoT system. For an optimal cluster head selection, adaptive fuzzy multi-criteria decision making approach (AF-MCDM) is used which is a combination of fuzzy AHP and TOPSIS method is introduced an energy efficient clustering algorithm. Regardless of the accessibility of every one of these works in the writing on shrewd group based directing for WSN, a large portion of the current frameworks utilized just the bunching methods dependent on separation. Anyway in a sensor organize, vitality effectiveness is a significant parameter that must be considered for improving the system life time. In this work, fuzzy standards are utilized for settling 
on increasingly effective choices to give an ideal incentive in the course disclosure process. The proposed model considered the sensors present in the IOT situation and consequently the current directing conventions which were proposed for steering in remote sensor systems are not ready to give ideal vitality utilization arrangement. In any case, the proposed vitality productive methodology for group arrangement and bunch based directing gives ideal outcomes by diminishing the vitality utilization and deferral. Additionally, the steering calculation created in this examination work is expanding the packet conveyance proportion by dodging hub disappointments. This is accomplished by the viable observing of vitality levels and along these lines dodging the packet drops happening because of hub disappointments by vitality. At last, it is seen that the proposed work gives ideal outcomes regard to the improvement concerning QoS in IoT based WSNs.

\section{Fuzzy applied energy aware clustering based routing}

In the uses of WSN, vitality effectiveness is a fundamental issue. By utilizing bunching with information total is a fundamental method to upgrade the vitality productivity through programming based conventions. In the bunching calculation, the group head choice is the primary issue. To take care of the above issue, we introduced a multi criteria basic leadership process. In this paper, a versatile fuzzy multicriteria basic leadership approach (AF-MCDM) is used in which fuzzy AHP and TOPSIS strategies are joined together for bunch head determination of the ideal basic leadership to build up a conveyed vitality effective grouping calculation. To accomplish information conveyance dependability invulnerable enlivened enhancement calculation is utilized to expand the information conveyance unwavering quality, two destinations should be considered all the while:

$>$ achieve low cost of inside cluster transmission;

$>$ achieve low cost of outside cluster transmission.

The complete expense of the connections between all the group individuals and their reporter $\mathrm{CHs}$ is called as the intra-bunch correspondence cost. The all out cost of the developed tree, the between bunch correspondence cost, is characterized as the entirety of the expenses of the connections between the $\mathrm{CHs}$ shaping that tree. The presented framework will be actualized in MATLAB stage. The display is evaluated and differentiated and before grouping and coordinating arrangement with respect to Quality of organization parameters, for instance, bundle movement extent, parcel adversity extent, throughput, sort out lifetime, all the way delay, channel load, jitter, bit botch rate, bolster inhabitance and imperativeness use. In this section we give the bits of knowledge with respect to the four parameters to be explicit current essentialness level of the $\mathrm{CH}$, space between Cluster Head and Sink, space among center and $\mathrm{CH}$ [10] and $\mathrm{CH}$ degree for convincing gathering improvement. In the wake of picking the $\mathrm{CH}$, various center points are allowed to join the framework by affiliating with a sensible $\mathrm{CH}$ in order to divert into a person from anyone of these packs and they are supported by the $\mathrm{CH}$ reliant on the use of cushioned rules. The system has 4 commitments from the data layer, 256 guidelines from the covered layers and 1 yield from the yield layer. In this structure, we used four semantic factors each with three levels including the proposed parameter $\mathrm{CH}$ degree. Hence the framework uses the triangular and trapezoidal support functions as in [21] nearby convolutional neural framework to outline decision principles. Also, the neuro-fuzzy standard framework utilizes the fuzzy participation capacities.

The vitality is the most significant asset which considered in remote sensor systems. Bunch heads are hubs expend more vitality than group individuals when they remember for collecting, handling and steering information. The leftover vitality is processed as following articulation.

$$
E r=E-E c .
$$

Expected information check is a remote connection metric and it predicts the connection quality from number of transmission and including retransmission of the information conveyance [25]. The EDX metric computes from (2) and (3).

Link EDX. EDX speaks to the forward and turn around information conveyance of the specific connection. The forward information conveyance (DDf) speaks to the likelihood of information bundle that effectively came to at beneficiary and switch information conveyance (DDr) speaks to the likelihood that affirmation parcel got effectively at the sender.

$$
L E D X=1 /(D D f \cdot D D r) \text {. }
$$

Route EDX. Route EDX finds the link quality of particular path Px. The Route EDX calculates from (5).

$$
R E D X=\sum_{i=1}^{n} L E D X i
$$

\section{Proposed Algorithm}

Input: set of nodes $\mathrm{N}$, node energy $\mathrm{E}$ and their position $(\mathrm{x}, \mathrm{y})$

Output: $\mathrm{M}$ number of Clusters and $\mathrm{M}$ cluster heads $\mathrm{CH}$

Step 1: For all nodes of $\mathrm{N}$ calculate Energy $\mathrm{E}$ and position $(\mathrm{x}, \mathrm{y})$

Step 2: $\forall \mathrm{Nn}$ transmit beacon and calculate distance $d$.

Step 3: K-means $(\forall \mathrm{Nn})$

Cluster set $x x=$ Call $(\forall \mathrm{Nn})$.

Step 4: for $I=1$ to $X X$

$$
\mathrm{CH}=\mathrm{Ni}(\mathrm{E}, \mathrm{d})>\mathrm{Nj}(\mathrm{E}, \mathrm{d})
$$

Step 5: $L E D X=1 /(D D f \cdot D D r)$

Step 6: $R E D X=\sum_{i=1}^{n} L E D X i$

Step 7: Return $\mathrm{CHm}$

Step 8: Check for current energy CE.

Step 9: If $C E<E$ goto step 4.

Step 10: if $\mathrm{CH}$ not active goto step 3 .

End.

Using this algorithm, the data collected by the sensor nodes are sent to the base station periodically. The algorithm is terminated whenever the energy level of half of the initial energy of the nodes are drained. 


\section{Performance Evaluation}

The introduced (FEACR) protocol is implemented in MATLAB software. The simulation environment details are given in Table 1. The proposed protocol is compared with FEEC-IIR [26] and FBCFP [27].

\section{Table I - Simulation Environment}

\begin{tabular}{|l|l|}
\hline Area & $1000 * 1000 \mathrm{~m}$ \\
\hline BS Location & $500-1000 \mathrm{~m}$ \\
\hline Number of Nodes & 200 \\
\hline Initial Energy & $0.7 \mathrm{j}$ \\
\hline Bandwidth & $30 \mathrm{Kbps}$ \\
\hline Packet Size & 750 Bytes \\
\hline Node Distribution & Random \\
\hline Antenna & Omni Directional \\
\hline
\end{tabular}

The parameters taken into account for performance evaluation are network lifetime, packet delivery ratio and delay time. Fig. 2 provides the performance evaluation in terms of packet delivery ratio.

From the Fig. 2, it is proved that the proposed FEACR is providing consistent delivery ratio even though more number of nodes are in the network. Figure 3 provides the performance comparison in terms of delay time in terms of milliseconds. Fig. 3 proves that the proposed method is performing well than other two methods and the delay time is reduced as number of nodes in the network increased. This is due to more alternate path are available for data transmission between source and destination. Fig. 4 provides the details of the comparison in terms of network life time in terms of seconds. From the Fig. 2, it is proved that the proposed FEACR is providing consistent delivery ratio even though more number of nodes are in the network. Fig. 3 provides the performance comparison in terms of delay time in terms of milliseconds.

\section{Conclusion}

In this paper, another directing calculation for IoT based sensor organizes that utilizations fuzzy principle based grouping approach for performing bunch based steering so as to upgrade the system execution. In this methodology, the bunch arrangement in WSNs used the vitality demonstrating for proficiently directing the packets through the use of AI utilizing convolutional neural system with fuzzy standards for weight alteration and henceforth the system lifetime is delayed. Additionally, we considered four parts in particular remaining vitality of the $\mathrm{CH}$, space between the $\mathrm{CH}$ and the sink hub, space between the sensor hub and the $\mathrm{CH}$ and the level of the $\mathrm{CH}$ which are significant components for the vitality usage and system life range.

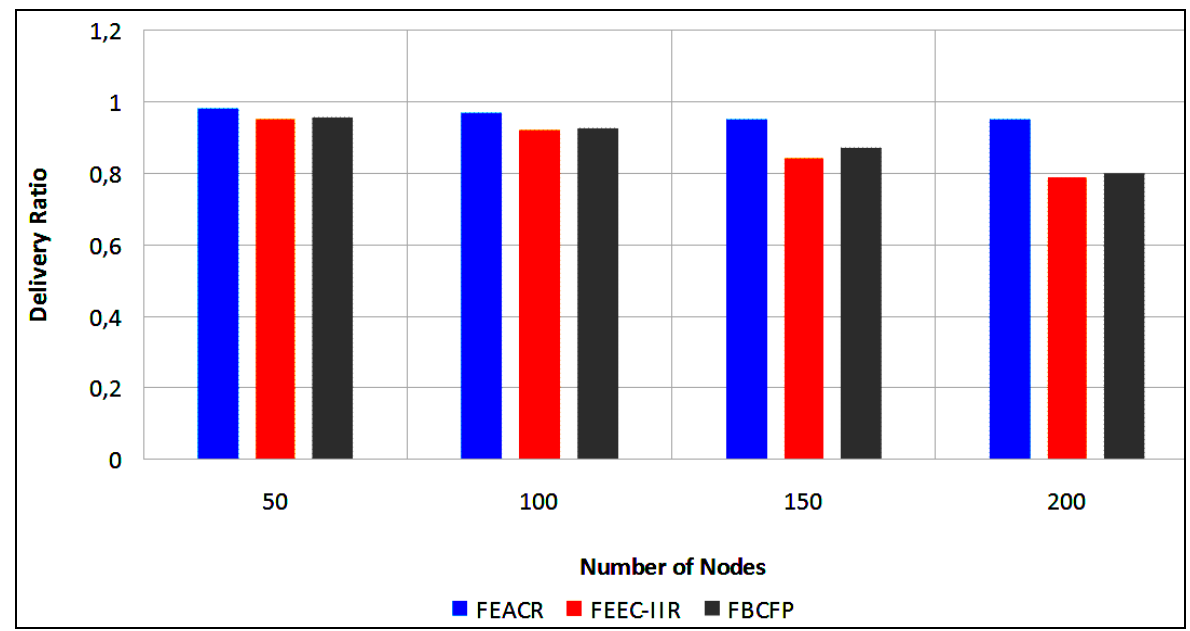

Fig. 2. Packet Delivery Ratio

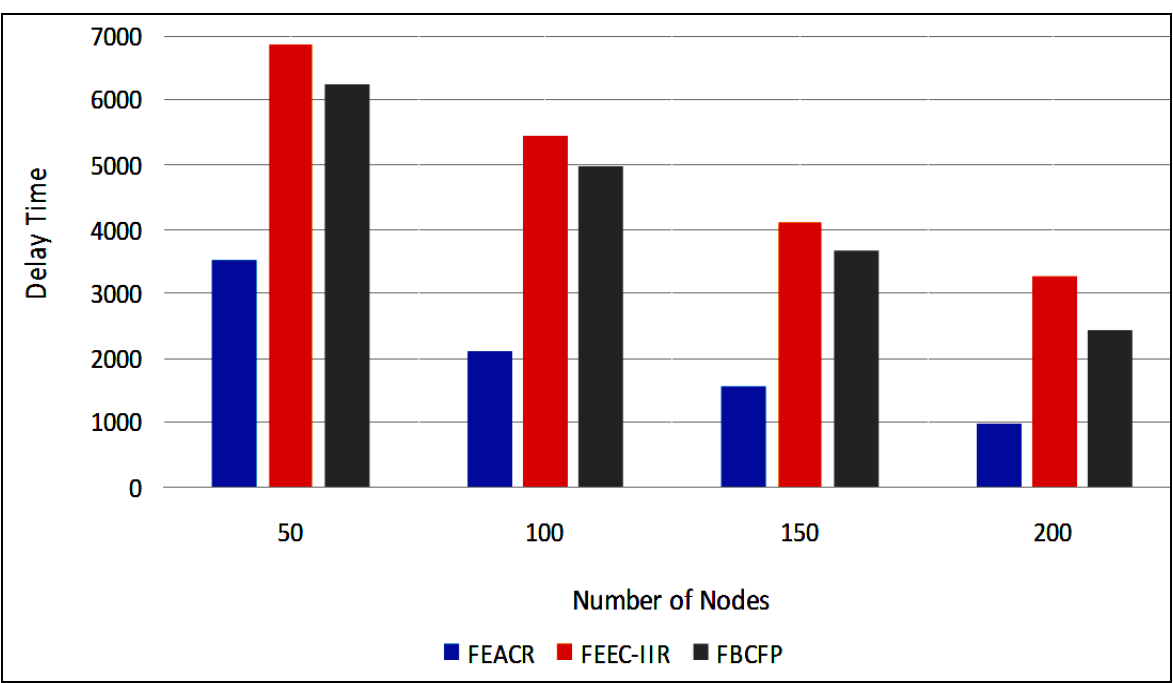

Fig. 3. Delay Time 


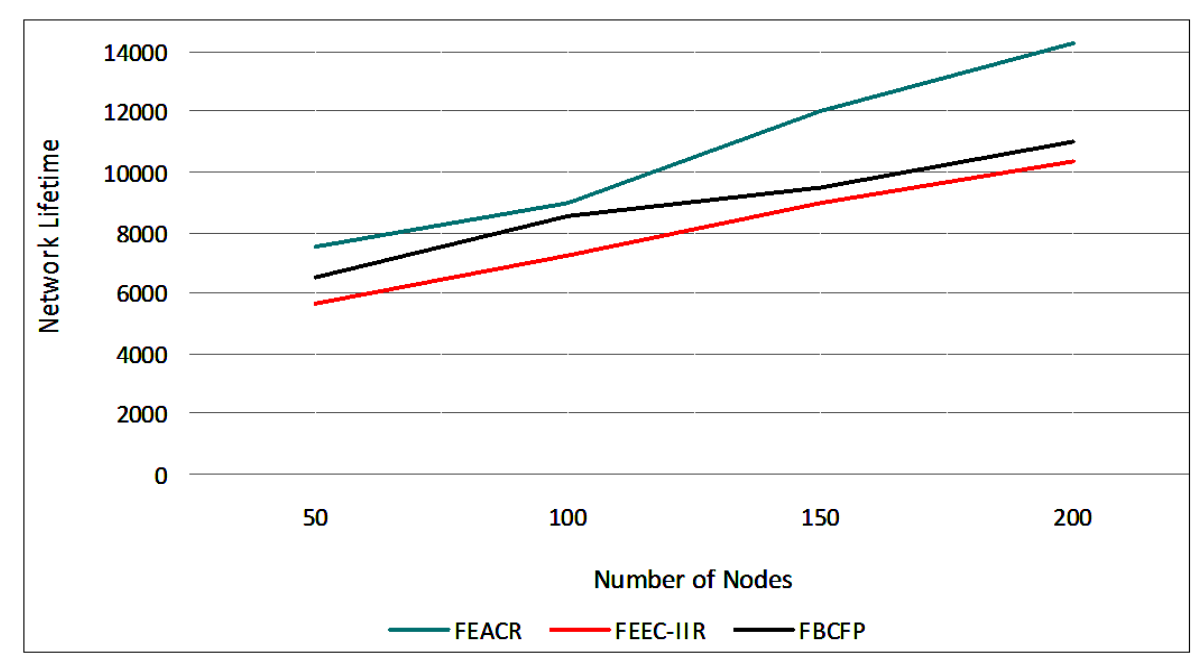

Fig. 4. Network Lifetime

We have assessed the proposed calculation utilizing recreations in which the previously mentioned segments were utilized as fuzzy factors. The yield estimation was utilized to decide the $\mathrm{CH}$ for the hub to join as a part. The reenactment result shows that FEACR gives the better execution as far as the packet conveyance proportion and system lifetime looked at and postpone time. As a feature of future work, it is wanted to give portability to the hubs, in low power and lossy systems and it is additionally arranged is to convey it in the ongoing condition.

REFERENCES

1. Lin, Jie, Wei Yu, Nan Zhang, Xinyu Yang, Hanlin Zhang and Wei Zhao (2017), "A survey on internet of things: Architecture, enabling technologies, security and privacy, and applications", IEEE Internet of Things Journal, Vol. 4, Is. 5, pp: 1125-1142.

2. Gazis, Vangelis (2017), “A Survey of Standards for Machine-to-Machine and the Internet of Things", IEEE Communications Surveys \& Tutorials, Vol. 19, Issue 1, pp. 482-511.

3. Sankar, S. and Srinivasan, P. (2016), "Internet of Things (Iot): A Survey on Empowering Technologies, Research Opportunities and Applications", International Journal of Pharmacy and Technology, Vol. 8, pp. 26117-26141.

4. Sankar, S. and Srinivasan P. (2017), "Composite Metric Based Energy Efficient Routing Protocol for Internet of Things", International Journal of Intelligent Engineering and Systems, Vol. 10, Issue 5, pp. 278-286.

5. Al-Fuqaha, A., Guizani, M., Mohammadi, M., Aledhari, M. and Ayyash, M. (2015), "Internet of Things: A Survey on Enabling Technologies", Protocols and Applications. IEEE Commun. Surv. Tutor, Vol. 17, pp. 2347-2376.

6. Sobral, J.V.V., Rabelo, R.A.L., Oliveira, D., Lima, J.C., Araujo, H.S. and Filho, R.H. (2015), “A Framework for Improving the Performance of IoT Applications", Proc. of the 14th Int. Conf. on Wireless Networks, Las Vegas, NV, USA.

7. Shah, B., Iqbal, F., Abbas, A. and Kim, K.-I. (2015), "Fuzzy Logic-Based Guaranteed Lifetime Protocol for Real-Time Wireless Sensor Networks", Sensors, vol. 15, pp. 20373-20391.

8. Kim, Hyung-Sin, Jeonggil, Ko, David, E. Culler, and Jeongyeup, Paek (2017), "Challenging the IPv6 Routing Protocol for Low-Power and Lossy Networks (RPL): A Survey", IEEE Communications Surveys \& Tutorials, Vol.19, Is.4, pp. 1-24.

9. Mohamed, Belghachi, and Feham, Mohamed (2015), "QoS Routing RPL for Low Power and Lossy Networks", International Journal of Distributed Sensor Networks, Vol. 11, Issue 11, DOI: https://doi.org/10.1155/2015/971545

10. Ammari, H.M. and Das, S.K. (2012), "Centralized and clustered k-coverage protocols for wireless sensor networks", IEEE Transactions on Computers, vol. 61, pp. 118-133.

11. Yardibi, T. and Karasan, E. (2010), "A distributed activity scheduling algorithm for wireless sensor network with partial coverage", Wireless Networks, vol. 16, pp. 213-225.

12. Shah, B. and Kim, K.-I. (2014), "A new real-time and guaranteed lifetime protocol in wireless sensor networks", Int. Journal of Distributed Sensor Networks, vol. 2014, pp. 11-22.

13. Li, F., Luo, J., Wang, W. and He, Y. (2015), “Autonomous Deployment for Load Balancing-Surface Coverage in Sensor Networks Wireless Communications", IEEE Transaction of Wireless Communication, vol. 14, pp. 279- 293.

14. Wei, P., Chu, S., Wang, X. and Zhou, Y. (2010), "Deployment of a reinforcement backbone network with constraints of connection and resources", Proc. of the IEEE 30th Int. Conf. on Distr. Comp. System (ICDCS), Genova, Italy, pp. 1019.

15. Li, F., Luo, J., Xin, S.Q., Wang, W.P. and He, Y. (2012), "Laacad: Load balancingk-area coverage through autonomous deployment in wireless sensor networks", Proc. of the IEEE 32nd Int. Conf. on Distr. Comp. System, Macau, China, pp. 566-575.

16. Wang, X., Li, L. and Ran, C. (2004), "An energy-aware probability routing in MANETs", Proceedings of the IEEE Workshop on IP Operations and Management (IPOM '04), pp. 146-151.

17. Patil, P. (2011), "Design of an energy efficient routing protocol for MANETs based on AODV", International Journal of Computer Science Issues, vol. 8, pp. 215-220.

18. Nand, P. and Sharma, S.C. (2011), "Probability based improved broadcasting for AODV routing protocol", Proceedings of the International Conference on Computational Intelligence and Communication Systems (CICN '11), pp. 621-625.

19. Gupta, D. Riordan and Sampalli, S. (2005), "Cluster-head election using fuzzy logic for wireless sensor networks", 3rd Annual Communication Networks and Services Research Conference (CNSR'05), pp. 255-260.

20. Kim, M., Park, S.H.Y., Han, J. and Chung, T.M. (2008), "CHEF: cluster head election mechanism using fuzzy logic in wireless sensor networks", 10th international conference on in Advanced communication technology, vol. 1, pp. 654-659. 
21. Mhemed, R., Aslam, N., Phillips, W. and Comeau, F. (20120, “An energy efficient fuzzy logic cluster formation protocol in wireless sensor networks”, Procedia Computer Science, vol.10, pp. 255-262.

22. Logambigai, R. and Kannan, A. (2016), "Fuzzy logic based unequal clustering for wireless sensor networks", Wireless Networks, vol. 22, no.3, pp. 945-957.

23. Taheri, H., Neamatollahi, P., Younis, O.M., Naghibzadeh, S. and Yaghmaee, M.H. (2012), “An energy-aware distributed clustering protocol in wireless sensor networks using fuzzy logic", Ad Hoc Networks, vol. 10, no. 7, pp. 1469-1481.

24. Youins, O. and Fahmy, S. (2004), "HEED: a hybrid, energy-efficient, distributed clustering approach for ad hoc sensor networks," IEEE Transactions on mobile computing, vol. 3, no. 4, pp. 366-379.

25. De Couto, Douglas S.J., Daniel, Aguayo, John, Bicket, and Robert, Morris, (2005), “A high-Throughput Path Metric for Multi-Hop Wireless Routing”, Wireless networks, Vol. 11, Issue 4, pp. 419-434.

26. Preeth, S.K.S.L., Dhanalakshmi, R. and Kumar, R. (2018), “An adaptive fuzzy rule based energy efficient clustering and immune-inspired routing protocol for WSN-assisted IoT system", J Ambient Intell Human Comput, https://doi.org/10.1007/s12652-018-1154-Z

27. Thangaramya, K. Kulothungan, R. Logambigai, M. Selvi, Sannasi Ganapathy and A. Kannan (2019), "Energy DOI: aware cluster and neuro-fuzzy based routing algorithm for wireless sensor networks in IoT", Computer Networks, Vol. 151, pp. 211-223, DOI: https://doi.org/10.1016/j.comnet.2019.01.024.

Надійшла (received) 17.09.2019

Прийнята до друку (accepted for publication) 20.11.2019

\section{Відомості ПРО Авторів / AвоUT тHE AUTHORS}

Амін Саліх Мохаммед - кандидат технічних наук, завідувач кафедри комп'ютерної інженерії, Lebanese French University; доцент кафедри програмного забезпечення та інформатики, Salahaddin University, Ербіль, Курдистан, Ірак; Amin Salih Mohammed - PhD, Associate Professor, Head of the Department of Computer Engineering, Lebanese French University; Associate Professor Dept of Software and Informatics Engineering, Erbil, Salahaddin University, Kurdistan Region, Iraq; e-mail: kakshar@1fu.edu.krd; amin.mohammed@su.edu.krd; ORCID ID: http://orcid.org/0000-0002-2993-6182

Саравана Балайі Б. - доцент кафедри інформаційних технологій, Lebanese French University, Ербіль, Курдистан, Ірак; B. Saravana Balaji - Associate Professor, Department of Information Technology, Lebanese French University, Erbil, Kurdistan Region, Iraq; e-mail: saravanabalaji.b@lfu.edu.krd; ORCID ID: http://orcid.org/0000-0001-9077-1658

Салем Баша М. С. - доцент кафедри обчислювальної техніки та інформатики, Mazoon College, Маскат, Оман; Saleem Basha M. S. - Associate Professor, Dept of Computing \& Informatics, Mazoon College, Muscat, Oman;

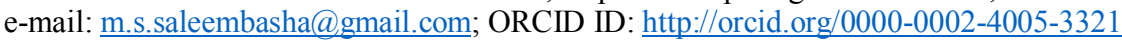

\section{Маршрутизація в ІоТ мережах, орієнтована на кластеризацію із нечітко застосованою енергісю} Амін Саліх Мохаммед, Саравана Балайі Б., Салем Баша М. С.

Анотація. Інтернет речей (ІоT) залежить від взаємозв'язку розумних та адресних гаджетів, що дозволяє їх самодостатність та активну поведінку з наявністю Інтернету. Розповсюдження інформації в ІоТ зазвичай покладається на додаток i вимагає налаштування правил управління, які повинні включати основні функції автоматичного налаштування (які регулюють поведінку системи під час виконання, з урахуванням даних про налаштування). У статті пропонується методологія побудови ІоТ з використанням нечіткого обгрунтування з метою досягнення умов виконання заявок. У цій ситуації нечітке обгрунтування використовується для розшифровки невизначених даних, переданих множиною фонетичних вказівок. Критерії життєвого статусу, ефекту QoS та площі концентратора приймаються як основні фактори, які можуть впливати на вибір груп, в той час як кожен захід містить певні підкритерії. Для маршрутизації, для покращення надійності передачі інформації використовується FEACR - нечітка застосована енергія, орієнтована на кластеризацію, заснована на джерелах енергії для IoT Networks. Направлення, засноване на об'єднання, це досвідчений спосіб зменшити використання життєвих сил. 3 тестів, проведених у цій дослідницькій роботі 3 використанням запропонованої моделі, показано, що запропонований підхід покращив роботу системи.

Кл ючов і слов а: Інтернет речей; маршрутизація; нечітка кластеризація; датчики.

\section{Маршрутизация в ІоТ сетях, ориентированная на кластеризацию с нечетко применяемой энергией} Амин Салих Мохаммед, Саравана Балайи Б., Салем Баша М. С.

Аннотация. Интернет вещей (IоT) зависит от взаимосвязи разумных и адресных гаджетов, что позволяет их самодостаточность и активное поведение при наличии Интернета. Распространение информации в ІоТ обычно возлагается на приложение и требует настройки правил управления, которые должны включать основные функции автоматической настройки (которые регулируют поведение системы во время выполнения, с учетом данных о настройках). В статье предлагается методология построения ІоТ с использованием нечеткого обоснования с целью достижения условий выполнения заявок. В этой ситуации нечеткое обоснование используется для расшифровки неопределенных данных, передаваемых множеством фонетических указаний. Критерии жизненного статуса, эффекта QoS и площади концентратора принимаются как основные факторы, которые могут влиять на выбор групп, в то время как каждое мероприятие содержит определенные подкритерии. Для маршрутизации, для улучшения надежности передачи информации используется FEACR - нечетко применяемая энергия, ориентированная на кластеризацию, основанная на источниках энергии для IoT Networks. Направление, основанное на объединение - это опытный способ уменьшить использование жизненных сил. Из тестов, проведенных в этой исследовательской работе с использованием предложенной модели, показано, что предложенный подход улучшил работу системы.

Кл юче в ы е слов а: Интернет вещей; маршрутизация; нечеткая кластеризация; датчики. 